The use of wrappers treated with a solution of iodine in potassium iodide has been found to retard the development of fungal rotting in grapes, tomatoes and oranges. Brown rot of plums and peaches has also been reduced by iodised wraps. The appearance and flavour of the fruit are not impaired, nor is ripening hastened. On the other hand, certain varieties of plums and peaches are adversely affected; they fail to ripen properly or may even turn black. When iodine is successful, it is because spores and young mycelium at the critical stage of infection are far more susceptible to its action than are old mycelium and the tissues of the fruit ; it can thus be used in concentrations sufficient to retard the development of moulds without causing damage to the fruit.

Further results of interest have been obtained from the continued study of the critical changes occurring in the apple at the climacteric, the most important of which is the identification of the active substance which is given off by apples at their climacteric change, and which itself stimulates this change in other apples. It was identified by absorbing it in bromine at $-65^{\circ} \mathrm{C}$., afterwards preparing a crystalline derivative identified as diphenylethylenediamine. The suggestion that the active substance is ethylene was, therefore, confirmed. About 1 c.c. is apparently given off during the whole of an apple's senescence.

An accidental discovery of great practical interest was made in the course of gas-storage trials of the 1934 season ; a set of ripe, strongly-smelling, post-climacteric apples was included in some of the experimental cabinets among several other varieties in the pre-climacteric condition. The ripe fruit caused a considerable amount of physiological damage to the rest of the fruit in the form of spotting round the lenticels.

Progress is recorded in the study of two common diseases of stored apples, namely, scald and low temperature breakdown. Scald is produced by changes in the tissues of the fruit occurring weeks or months before the injury becomes apparent; prevention by oiled paper wrappers is chiefly efficient during these early predisposing changes. Scald was also almost completely prevented in Newton Wonders stored at $3^{\circ} \mathrm{C}$. by brief intermittent warming of the fruit at $15^{\circ} \mathrm{C}$. Scald is probably due to an excessive accumulation in the superficial tissues of the fruit of some volatile substance.

Among other points in the report to which attention may be directed is the investigation into the stability of synthetic vitamin C (ascorbic acid) during canning. It was added to runner beans, which do not naturally contain much vitamin C, to spinach and to apples and apple jelly ; in no case was the loss greater than 25 per cent during the canning.

This brief summary of some of the investigations described in the report will give some idea of the range of the researches carried out by the Board, and their importance for the nation's food supply.

\title{
Obituary
}

\section{Dr. Griffith Evans}

$\mathrm{D}^{\mathrm{R}}$ GRIFFITH EVANS, whose death on December 7 we regret to announce, was a pioneer in the study of protozoology in connexion with infections, and the first man to associate trypanosomes with the production of disease. He was born at Tymawr, near Towyn, Merionethshire, on August 7, 1835. After studying medicine for a short time with a medical practitioner at Towyn and Aberdovey, he entered the Royal Veterinary College, London, where he qualified as M.R.C.V.S., and later passed into the Royal Artillery, with which regiment he served in Canada during the American Civil War. During his years of service in Montreal he registered in the Medical Faculty of MoGill University, and graduated M.D., C.M. in 1864.

On his return to England in 1871, Evans was transferred to the Army Service Corps and continued his medical studies at King's College, London, and elsewhere until 1877, when he was sent to India. It was there that his great work on blood parasites was carried out. Microscopy had been his hobby since his earliest student days, and an important part of the equipment which accompanied him to India was a portable microstand, the best lenses which he could obtain up to $1 / 12$ th immersion, a suitable condenser, etc.

On arrival in India, Evans was appointed to investigate an endemic disease which for many years had been fatal to cavalry and artillery horses; by microscopic examination of the blood, which revealed the specific bacillus in the blood of every patient, Evans at once proved the disease to be anthrax fever. What surprised him most in his investigations was the fact that the first change in the blood seen under the microscope was a great increase in the number of the large white corpuscles before the bacillus could be seen; moreover, when the bacilli came, they appeared to be closer to the white corpuseles than to the red. He reported his conviction that the large 
granular corpuscles had an important relationship to the bacilli, though he was unable to prove what that relationship might be. This was in 1878, six years before Metchnikoff discovered them to be phagocytes, and at a time when Evans himself did not know even how to fix and stain microbes in the blood for microscopic observation.

In 1880 Evans began his work on surra. He was requested to proceed to Dera Ismael Khan, where surra had been fatal to horses and camels for many years; and upon studying the reports which had already been made upon the disease he at once reached the opinion that it was due to a parasite of the blood -an opinion which had never before been formed. After much opposition, he gained permission to carry out his investigations with a free hand, to make what experiments he wished upon sick and healthy animals, and to kill the animals at any stage of the disease. His first act was to examine microscopically the blood of a surra patient : it was swarming with parasites. Though Koch had not yet made his classical postulates, and though Evans did not know the nature of the microbes revealed to him, he immediately associated them with the production of the disease. They were the parasites which, at first called Trichomonas evansi, are now known as Trypanosoma evansi.

Evans at once took steps to show his newly. discovered microbes to Dr. Timothy Lewis, the discoverer of the parasite in the blood of the brown sewer rat-now called Trypanosoma lewisi. Without hesitation Lewis declared that the two parasites were, with some slight difference, morphologically alike; but he emphatically denied that they were pathogenic. His rats were, in his opinion, healthy, and he did not believe that Evans's microbes were the cause of surra. Nevertheless, Evans continued his investigations eagerly, seeking to prove that a definite relationship existed between the variable number of the parasites present in the blood and the course of the symptoms. Official opinion was strongly against him. In fact, in Evans's own words, the SurgeonGeneral, the Chief Sanitary Officer and all the senior medical officers "sat upon me heavily", but the Government printed his reports, and he had the gratification of knowing that his statements spurred on a number of younger men to continue investigations along lines which he had laid down.

Evans returned to England in 1885, and after further work in Crookshank's laboratory, King's College, London, retired from the army in 1890. In 1917 he was awarded the Mary Kingsley Medal by the Liverpool School of Tropical Medicine, in recognition of his distinguished scientific work, and on that occasion he wrote a short autobiographical memoir, which was published in vol. 12 of the Annals of Tropical Medicine and Parasitology. A year later the Royal College of Veterinary Surgeons awarded him its John Steel Medal.

Dr. Griffith Evans celebrated his hundredth birthday in August last, when he was the recipient of a presentation scroll from the Royal Veterinary College and of many congratulatory messages (see NATURE, August 3, p. 173 and August 17, p. 251).

\section{Dr. J. H. Breasted}

We regret to record the death of Dr. J. H. Breasted, the well-known Egyptologist, founder and director of the Oriental Institute of the University of Chicago, which took place on December 2, in the Medical Center Hospital, New York, at the age of seventy years. Dr. Breasted, who had returned to the United States from Italy only a few days previously, was thought to be suffering from an attack of the tropical malaria to which he had been subject for some years; but his illness proved to be due to hæmolytic streptococci, and terminated fatally.

James Henry Breasted was born on August 27, 1865, and was educated at the Chicago Theological Seminary and the University of Berlin. At the latter, he devoted himself particularly to Egyptological studies; and, indeed, the abiding influence of the Berlin school of thought was apparent throughout his work. In 1894, he became assistant in Egyptology in the University of Chicago, and in 1901 was made director of the Haskell Oriental Museum. Among other university appointments, he occupied the professorial chair in Egyptology from 1905 until 1933. His more important activities outside the University included a mission to the museums of Europe in 1900 to prepare documents for the Imperial Egyptian Dictionary for a commission of the Royal Academies of Germany, and the direction in the field of the expedition of the University of Chicago to Nubia in 1905-7.

By the close of the first decade of the present century, Breasted's international reputation as an Egyptologist and an ancient historian stood high, owing in no small measure to his attractive, and at the same time scholarly, "History of Ancient Egypt" (1905), and his excerpts from original documents of the Egyptian historical records, of which he had published five volumes. His strength, however, as was proved by his later activities, was even greater in the organisation of research than in his quality as a research worker. His interests had transcended the bounds of Egyptology and at a comparatively early stage of his career he had begun to formulate plans for a scheme of research into the origins and growth of civilisation on a grand scale, the theatre for its operation-the ancient East-being determined by the fact that here the lengthy span and the continuity of man's existence as a member of organised society could be investigated on archæological sites with a wealth of detail that was impossible in any other part of the world.

These plans did not attain fruition until after the Great War. As the result of an expedition of reconnaissance through the Near East in 1919-20, Breasted mapped out a plan of campaign for research in the field which covered all the main historical, geographical and chronological strategic points in Egypt and Western Asia, extending from the time of palæolithic man in the Nile Valley and Mesopotamia down to the days of the Persian Empire. As a necessary complement and accompaniment was an institute for the interpretation of results and further i esearch at headquarters in Chicago, which so far as library and laboratory work were concerned was to be duplicated on a reduced scale at headquarters 